\title{
The Impact of China One Belt One Road on Abidjan Port Development Based on Gravity Model
}

\author{
Pascal Kany Prud'ome Gamassa and Yan Chen
}

\begin{abstract}
Being one of the most competitive ports in West Africa, Abidjan Port aims to become the leading port in the region. In this article, the impact of China One Belt One Road strategy on Abidjan port is being studied and analyzed by the Chinese investment on Abidjan port and also the analysis of the trade potential between China and Ivory Coast. The Gravity Model is applied through a Hausman test and an empirical test to determine the significant variables affecting the bilateral trade between the two countries. During the application of the Hausman test, the null hypothesis was rejected and the fixed effect model was found to be the most appropriate model to use. The results found, showed that the population and the gross domestic product (GDP) are the two factors which have a great influence on the bilateral trade between these two countries. It has also been found that there is a large trade potential between the two countries. The time series model is used with the autoregressive model to forecast the China export trade value to Ivory Coast from 2016 to 2018. Some strategies have also been suggested for the development of Abidjan port with the support from the China One Belt One Road strategy.
\end{abstract}

Index Terms - Trade potential, one belt one road, gravity model, port development.

\section{INTRODUCTION}

Built in 1950, Abidjan port is the main port of Ivory Coast, which is the second largest economy of West Africa. Ivory Coast and China established their diplomatic relations in 1983 and since 2009 China has become one of its main trade partners. Because of its strategic location, Ivory Coast is the center of economic activity in West Africa. Having been implemented in 2013, the Chinese "One Belt One Road" strategy follows the Chinese "Go out" strategy that was implemented in the beginning of this Century. Its main objective is to link Asian, European and African countries by maritime routes and overland roads, involving building many infrastructures in those countries. This initiative received the support and active participation from many Asian, European and African countries as it will accelerate the establishment of a multi-tier cooperation platform [1]. The 21st Maritime Silk Road strategy will uphold the basic principle of open cooperation, harmonious inclusiveness, market operation and mutual benefits [2]. It will build a transcontinental China oriented infrastructure and will have a positive impact on Chinese outbound investment [3], [4]. Through this strategy, land and maritime passages will be built and the two-way international logistics system will be established and

Manuscript received January 16, 2017; revised May 7, 2017. This work was supported in part by the Liaoning Provincial Government.

The authors are with Dalian Maritime University, Dalian, China (e-mail: gamassa_kany@yahoo.fr, chenyan_dlmu@163.com). developed [5]. Many countries including Ivory Coast that were not part of the "One Belt One Road" strategy, proposed to China to take part of this innovative strategy and later Ivory Coast was officially accepted. During the Chinese "Go out" strategy many Chinese Private and State-owned enterprises invested in this West African country. Thus, through the China "One Belt One Road" strategy, more Chinese enterprises are expected to invest in Ivory Coast. Because of the net increase of the labor cost in China, many Chinese factories will move to Africa, as it has already happened in Ethiopia since the labor cost in African countries is still low. Ivory Coast has a port that serves as a gateway port for neighboring countries such as Mali and Burkina Faso and is also a politically stable country. It is considered by China as a potential economic leader of West Africa in the coming years. Being the most populated region of Africa, with a huge population estimated at $320,347,000$ Million people, West Africa is considered to have the biggest market in the continent by many Chinese investors.

In order to find a solution to the container congestion problem that Abidjan port currently faces, the Abidjan port authority decided to build a second container terminal that will be able to receive bigger ships and correctly handle the containers. In 2014, Ivory Coast received $\$ 875$ million US Dollars from China via the China Eximbank to finance this project, an amount that represents $85 \%$ of the total amount needed by the Abidjan Port Authority for this project [6]. Until now, it is still the largest investment made by China in the development of a port in Africa. China being far from Europe, highly investing in Ivory Coast is good, since it is close and has a direct maritime route to Europe making it a greater advantage. Ivory Coast can therefore become a future base for many Chinese factories, as the goods that they will produce can easily not only reach the West African market, but also the European market. Abidjan port will therefore play an important role because a large quantity of equipment will be imported from China by Chinese investors via this port to open up factories. And the products produced by these factories will be exported also via the same port hence making work easier. The questions to be asked are, why did China invest such a big amount of money for the development of Abidjan port? How can Abidjan port benefit from Chinese new strategy? Can the impact of the China "One Belt One Road" strategy easily be seen? What is the current trade situation between China and Ivory Coast? Is there any trade potential between the two countries? What strategies can the Abidjan Port Authority use to develop Abidjan port? This article provides answers to these questions. It is well known that the higher the demand of a country for goods becomes, the higher its trade volume may increase, thus the Gravity 
Model will be used in this article to estimate the trade potential between China and Ivory Coast and a forecast will be made on the China export trade value to Ivory Coast.

\section{LITERATURE REVIEW}

Abidjan port is a port that constantly welcomes vessels or ships coming from China main ports such as Shanghai port or Guangzhou port. China has a better understanding that the development of a port directly contributes to the economic development of a country. Indeed, being the second largest economy in the world, it has become an economic model for many other countries and the topics related to its "One Belt One Road" strategy implementation are considered to be of great importance by many Chinese and foreign researchers. From the Fig. 1 below, it can be seen that the China "One Belt One Road" strategy impact on Abidjan port is evident as China is really engaged in the development of this port. Though many articles and research papers were written about this topic, but until now no African researcher has ever written about this similar topic, making this article being of great significance for future other studies or research.

It has been noted by many researchers that some factors may influence the trade potential between two countries. Birahim Bouna Niang in his article estimated the trade potential of Senegal and Morocco based on an augmented gravity model that revealed that this potential was underexploited towards African trade partners and other parts of the World such as Europe, Asia and Latin America [7]. Gebreyesus Gebrehiwot and Bahre Gebru estimated Ethiopia's trade potential with major trading partners using a dynamic gravity approach based on a panel dataset. The findings did not only reveal that the dynamic gravity model fits the data well, indicating the presence of hysteresis in trade but it was also found that the traditional gravity variables are all significant [8].

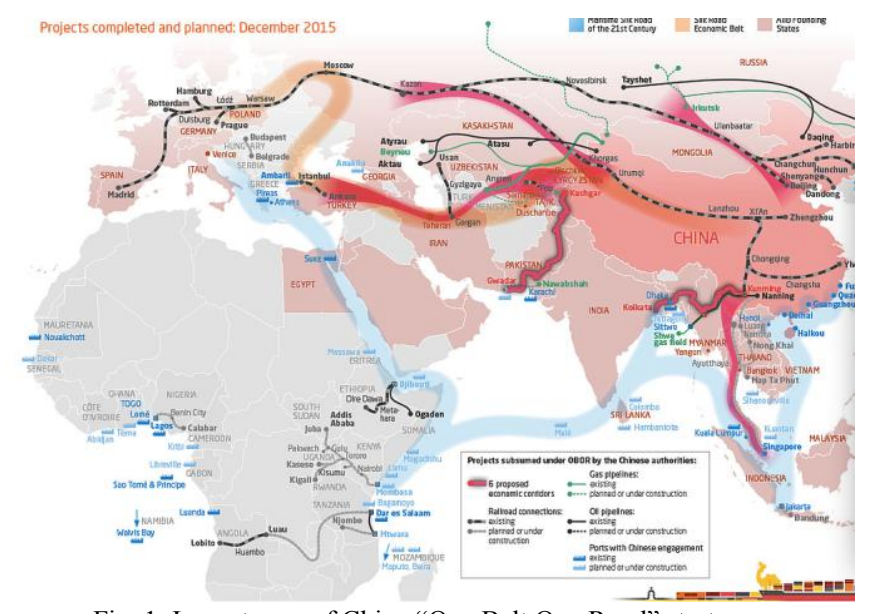

Fig. 1. Impact map of China "One Belt One Road" strategy.

Afolabi O. Luqman, Nor Aznin Abu Bakar and Azman Aziz Mukhriz Izraf in their study, examined the bilateral trade flow across ECOWAS-15 nations with the use of a panel and cross section for the period of 1981-2013 and investigated the formational impact of regional trade integration agreements on trade flows within a group of countries using the same currencies and ECOWAS at large. They used various techniques of estimation for the gravity model, mainly static and dynamic and the results of their study showed the presence of a strong relationship among the factors of trade flows and regional trade integration agreements [9]. Abdulmenaf Sedjini and Ilirjana Kraja in their paper provided some theoretical and empirical considerations regarding trade development with the focus on export-imports in Albania in relation to the Free Trade Agreements, and applied the gravity model of trade for Albanian case in relation to its 27 export/imports countries. Their findings resulted in stable trade flow for Albania [10]. Yasir Tariq Mohmand, Aneel Salman, Khurrum Shahzad Mughal, Muhammad Imran and Nedim Makarevic used the gravity model in their article to analyze the export environment of Pakistan. The results showed that Pakistan still has plenty of export potential with most of its partner countries and as such Pakistan can possibly reduce or control the trade deficit by targeting these countries [11]. Henry Tumwebaze Karamuriro and Wilfred Nahamya Karukuza in their article examined the factors affecting Uganda's export using an augmented gravity model of trade, based on a panel dataset covering the period 1980 to 2012 . The results showed that Uganda's gross domestic product (GDP), importer's GDP, importer's GDP per capita, per capita GDP difference between Uganda and its trading partners, real exchange rate, official common language and contiguity had a positive and statistically significant effect on Uganda's exports. However, Uganda's GDP per capita and distance with its trade partners had a negative effect on Uganda's export flows [12]. Li Kai Jun in his research paper studied the China's export trade flow and calculated its trade potential, using the gravity model based on a panel of data from 2002 to 2006 of China and 18 of its major trade partners. The findings revealed that China's export trade already reached a saturation point [13]. Wang Ting in his research paper analyzed the Zhejiang clothing export trade potential under the "Belt and Road" by using traditional trade gravity model, based on the data of clothing export in Zhejiang province in China. The results showed that there is still a vast market potential for Zhejiang clothing in Brazil, Australia and Africa despite their far distance from Zhejiang province. [14].

$\mathrm{Vu}$ Van Trung and Nguyen Anh Thu on their side examined the trade potential of climate smart goods of Vietnam, employing the gravity model with panel data for bilateral trade between Vietnam and its 45 partners from 2002 to 2013 with an objective of identifying the determinants explaining Vietnam's trade of climate smart products. The estimation results revealed that the economic size, market size, distance, real exchange rate, border, the quality of infrastructure of both Vietnam and its trading partners play a major role in bilateral trade of climate smart goods [15]. Ehsan Rasoulinezhad and Gil Seong Kang explained in their paper the bilateral trade patterns between South Korea and thirteen countries members of the Organization of the Petroleum Exporting Countries over the period 1980-2014 using a gravity model. The findings showed that the trade pattern between South Korea and OPEC member countries relies on the Heckscher-Ohlin theory and the South Korea OPEC trade is well explained by the factors that influence the energy security of South Korea such as oil reserves, transportation costs and political stability [16]. Chi-Chen 
Wang, Yi-Hsien Tu and Hsien-Lun Wong evaluated three Multivariable Fuzzy Time Series Model and traditional time series models for the comparison of forecasting accuracy of China exports. The results found indicated that Multivariable Fuzzy Time Series Model is more appropriate for the short-time prediction than traditional time series models [17]. Johannes Ledolter did not only study the bias and the mean square error of the least squares estimate and the bias-corrections proposed by Kendall and Quenouille; but he also studied the mean square forecast error and the coverage of the $95 \%$ prediction interval when using the bias least squares estimate or one of its bias corrected versions. He found that the estimation bias though it matters little for point forecasts, but it affects the coverage of the prediction intervals [18].

\section{GRAVITy Model Methodology}

According to the law of universal gravitation discovered by Newton in 1687, the standard gravity model simply describes that the trade between two countries is determined positively by each country's GDP and negatively by the distance between them [19]. The gravity model is a model widely used to predict trade flows, which was developed by Jan Tinbergen (1962) and Poyhonen (1963) who first applied the model to international trade flows, while Linneman (1966) related trade between country $i$ and country $j$ to the proportion of the product of both countries GDP and to the distance between them as a proxy for transaction costs [20], [21]. This can be expressed as:

$$
X_{i j}=A\left(Y_{i} Y_{j}\right) / D_{i j}
$$

where $X_{i j}$ represents the bilateral trade between country $i$ and country $j, Y_{i}$ and $Y_{j}$ are countries $i$ 's and $j$ 's GDP, $D_{i j}$ is the geographical distance between the two countries' capital cities and $A$ is a constant. In order to facilitate the empirical test, the original model is transformed into a linear logarithm form and the random error term is added:

$$
\operatorname{LnX} X_{i}=\beta_{0}+\beta_{1} \ln \left(Y_{i} Y_{j}\right)+\beta_{2} \ln D_{i j}+u_{i j}
$$

where $\beta_{0}$ represents a constant, $u_{i j}$ is an error term and the coefficients $\beta_{1}$ and $\beta_{2}$ reflect the $X_{i}$ elasticity towards $Y_{i}, Y_{j}$ and
$D_{i j}$. Based on this article research objective and collated literature, in addition to the GDP and the distance which are the two basic variables of the gravity model, the population and the trade policy, have been chosen as explanatory variables that will be added and applied to (2). It is important to note that in this article, the trade policy here refers as whether the country which has bilateral trade with China is or is not also a member of the World Trade Organization. Thus, WTO will be considered as a dummy variable.

China being considered as the export country, therefore export is the dependent variable and based on (2), a suitable model for China's bilateral trade can be established:

$$
L n T_{c i}=\beta_{0}+\beta_{1} \ln G_{c} G_{i}+\beta_{2} \ln P_{c} P_{i}+\beta_{3} \ln D_{c} D_{i}+\beta_{4}(W T O)+U_{c i}
$$

where $T_{c i}$ represents China and the trading partner, $c$ is the country's export trade value (of which $i$ represents the year) $G_{c} G_{i}, P_{c} P_{i}$, and $D_{c} D_{i}$ represent the GDP of two countries, the Population of two countries and the Distance between two countries capitals. WTO reflects whether the trading partner countries are WTO members. Because the simple trade gravity model between China and Ivory coast is not enough to explain the barriers to trade between the two countries and their trade potential for the future, thus other gravity models between China and Ghana, Togo, Nigeria, Benin, Senegal will be also constructed. The choice of these West African countries can be explained by the fact that with Ivory Coast, they are China main's trade partners in the region and have the most competitive ports of West Africa. This will therefore give the equation below:

$$
L n T_{c i}=\beta_{0}+\beta_{l} \ln D_{c} D_{i}+\beta_{2} \ln G_{c} G_{i}+\beta_{3} \ln P_{c} P_{i}+\beta_{4}(W T O)+U_{c i}
$$

where $T_{c i}$ will represent the export value of China to the above 6 West African countries $(i=1,2,3,4,5,6) ; \beta_{0}$ is a constant, $D_{c} D_{i}$ is the distance between China's capital and the 6 West African countries capitals $(i=1,2, \ldots, 6), G_{c} G_{i}$ is the result of China GDP multiply by the 6 West African countries GDP $(i=1,2, \ldots, 6), P_{c} P_{i}$ is the result of China population multiply by the 6 West African countries population $(i=1,2, \ldots, 6)$. WTO represents the World Trade Organization, in which every country mentioned above is a member. If the two countries are members of the WTO, the variable will have the value of 1 and 0 otherwise.

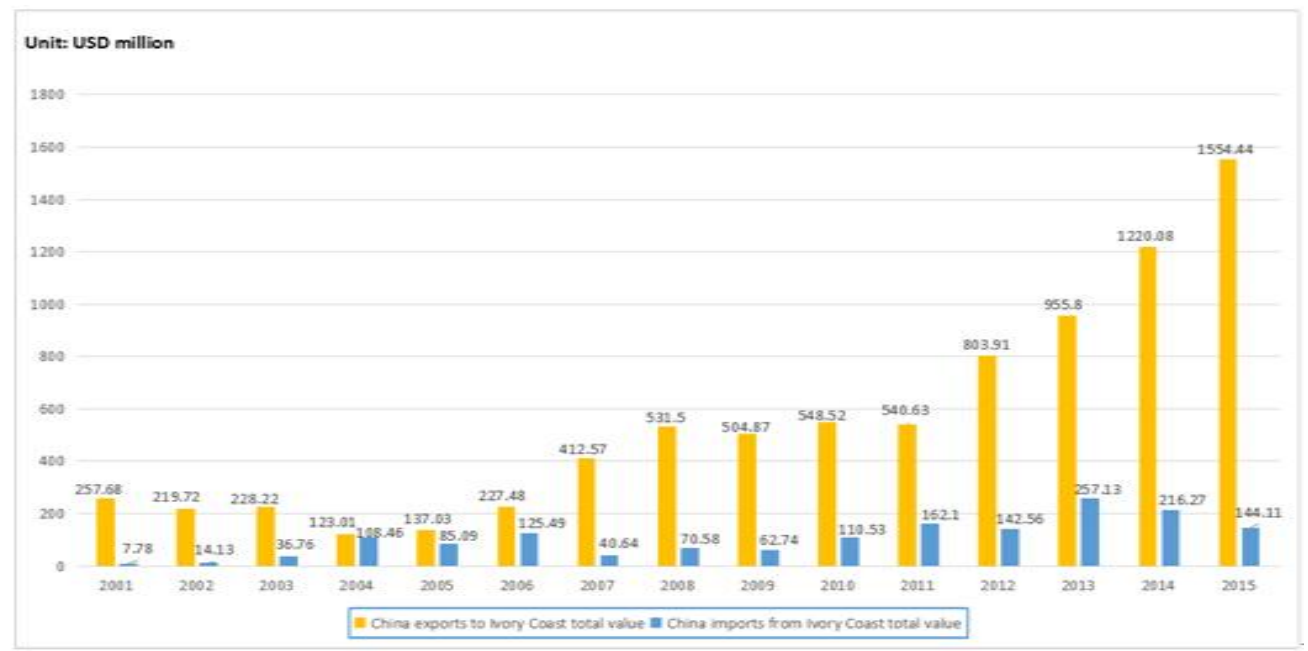

Fig. 2. Graph of China-Ivory Coast import-export total trade value (2001-2015) Source: China State Statistical bureau, 2016. 


\section{ANALYSIS OF THE COLLECTED DATA}

The chosen time period under study from 2001 to 2015 , it can be explained by the fact that China became an effective member of the World Trade Organization in 2001 and during the time this article was written, the China-Ivory Coast trade value of the year 2016 was not yet available on the official website of the National Bureau of Statistics of China. Fig. 2 below is an important figure.

It describes the total trade value of China exports and imports to and from Ivory Coast from 2001 to 2015. It is noticeable that the trade value between the two countries is really characterized by an imbalance in favor of China. Therefore, China exports more to Ivory Coast than it imports from this West African country. The fact that the China export trade value to Ivory Coast has been greatly increasing starting from the year 2011 is because before this year, Ivory Coast went through some serious political crisis.

China and Ivory Coast are two very active members of the World Trade Organization and the China top 10 exports of goods to Ivory Coast for the year 2015 which are the latest data can be seen in Table I below [22].

TABLE I: CHINA TOP 10 EXPORTS OF GOODS TO IVORY COAST IN THE YEAR 2015 (VALUE IN MILLIONS OF US DOLLARS ) SOURCE: UN COMTRADE DATABASE, 2015

\begin{tabular}{|c|l|c|}
\hline \multicolumn{3}{|c|}{ SOURCE: UN COMTRADE DATABASE, 2015 } \\
\hline \multicolumn{1}{|c|}{ Goods } & Value \\
\hline 1 & Electrical, electronic equipment & 171.0 \\
\hline 2 & Nuclear reactors, boilers, machinery, etc. & 132.8 \\
\hline 3 & Vehicles other than railway, tramway & 102.8 \\
\hline 4 & Iron and steel & 99.6 \\
\hline 5 & Miscellaneous chemical products & 82.6 \\
\hline 6 & Articles of iron or steel & 73.9 \\
\hline 7 & Plastics and articles thereof & 72.4 \\
\hline 8 & $\begin{array}{l}\text { Articles of apparel, accessories, not knit or } \\
\text { crochet }\end{array}$ & 71.3 \\
\hline 9 & Ceramic products & 66.4 \\
\hline 10 & $\begin{array}{l}\text { Fish, crustaceans, molluscs, aquatic } \\
\text { invertebrates }\end{array}$ & 59.3 \\
\hline
\end{tabular}

China in return mainly imports cotton, cocoa, wood, ores, slag, and ash from Ivory Coast. The sources of the data used for the application of the gravity model in this article are the National Bureau of Statistics of China for the export trade value statistic data of China to Ivory Coast, Ghana, Togo, Benin, Senegal, Nigeria [23]; the World Bank database for the gross domestic product and the population number of each of the seven countries [24]; the Webpage of Travel Distance Calculator between cities for calculating the distance between Beijing and the capital cities of the countries under study [25]; the World Trade Organization official website to verify if yes or no the countries under study are members of the WTO [26].

\section{A. Hausman Test Results}

Hausman test was applied to determine which of the random effect model or the fixed effect model is the most appropriate model to use for this study case. As it can be seen in Table II, the Prob. value is significantly below 0.05 , thus the fixed effect model should be used.

The fixed effect model has a problem to estimate variables that do not change over time because of inherent transformation combs out such variables, and as such the dummy variable WTO and the distance need to be dropped [27]. This will give the below equation:

$$
L n T_{c i}=\beta_{0}+\beta_{1} \ln G_{c} G_{i}+\beta_{2} \ln P_{c} P_{i}
$$

TABLE II: HAUSMAN TEST

Correlated Random Effects - Hausman test

Pool: POOL

\begin{tabular}{lllll}
\hline Test Summary & Chi-Sq.Statistic & \multicolumn{2}{l}{$\begin{array}{l}\text { Chi-Sq.d. } \\
\text { f }\end{array}$} & Prob. \\
\hline \hline $\begin{array}{l}\text { Cross-section } \\
\text { random }\end{array}$ & \multicolumn{2}{c}{$\begin{array}{l}34.4506 \\
44\end{array}$} & 2 & 0.0000 \\
\hline \hline & Cross-section random effects test comparisons: & \\
Variable & Fixed & Random & Var(Diff) & Prob. \\
\hline \hline LOG(GG?) & 0.650810 & 0.802036 & 0.000759 & 0.0000 \\
\hline \hline LOG(PP?) & 0.597046 & -0.613667 & 0.045081 & 0.0000 \\
\hline \hline
\end{tabular}

TABLE III: RESULTS FOUND

Sample: 2001-2015

Include observation: 15

Cross-section included: 6

Total pool(balanced)observation: 90

Linear estimation after one-step weighting matrix

\begin{tabular}{|c|c|c|c|c|}
\hline Variable & Coefficient & Std.Error & t-Statistic & Prob \\
\hline $\mathrm{C}$ & -39.67912 & 7.600055 & -5.220899 & 0.0000 \\
\hline LOG(GG?) & 0.633173 & 0.037765 & 16.76590 & 0.0000 \\
\hline LOG(PP?) & 0.593026 & 0.236580 & 2.506664 & 0.0142 \\
\hline \multicolumn{5}{|l|}{$\begin{array}{l}\text { Fixed Effects } \\
\text { ( Cross) }\end{array}$} \\
\hline NIGERIA-C & -1.414181 & & & \\
\hline BENIN-C & 1.382405 & & & \\
\hline TOGO-C & 2.040552 & & & \\
\hline GHANA-C & -0.151348 & & & \\
\hline SENEGAL-C & -0.714328 & & & \\
\hline $\begin{array}{l}\text { IVORY_COAST- } \\
\mathrm{C}\end{array}$ & -1.143100 & & & \\
\hline \multicolumn{5}{|l|}{ Effects Specification } \\
\hline \multicolumn{5}{|c|}{ Cross-section fixed(dummy variables) } \\
\hline \multicolumn{5}{|l|}{ Weighted Statistics } \\
\hline R-squared & 0.953097 & \multicolumn{2}{|c|}{ Mean dependent var } & 12.59877 \\
\hline Adjusted R-squared & 0.949093 & \multicolumn{2}{|c|}{ S.D.dependent var } & 3.662336 \\
\hline S.E. of regression & 0.311780 & \multicolumn{2}{|c|}{ Sum squared resid } & 7.970970 \\
\hline F-statistic & 238.0390 & \multicolumn{2}{|c|}{ Durbin-Waston stat } & 0.720084 \\
\hline Prob (F-statistic) & 0.000000 & & & \\
\hline
\end{tabular}

\section{B. Empirical Test Results}

An empirical test is made to confirm if the explanatory variables chosen are significant and whether they will be able to explain the China's bilateral trade with the six West African countries. To proceed to the empirical test, the index and data of each country are gathered together according to the model, and then the Eviews 8.0 software is used to carry on the regression analysis of the panel data. According to the type of data, and of the result of the above Hausman test which demonstrated that the random effect model could not be used in this case, the generalized least square method and the fixed effect model were used to analyze and measure the panel data covering the period of the year 2001 up to the year 2015. However, after the application of the fixed effect model the D.W. found was 0.621 , which indicates that the residual 
sequence of the model may be auto correlated. The weighted fixed effects model is then used to see whether the auto correlation of the residual sequence has been improved. The results can be found below in Table III.

Based on (5), the results found after applying the Eviews regression analysis with the weighted fixed effect model are:

$$
L n T_{c i}=-C-39.679+0.633 \ln G_{c} G_{i}+0.593 \ln P_{c} P_{i}
$$

$$
\begin{array}{ll}
R^{2}=0.953 & \text { Adjusted } R^{2}=0.949 \\
D . W .=0.720 & F=238.039
\end{array}
$$

(China-Ivory Coast: $c=-1.143$, China-Nigeria: $c=-1.414$, China-Ghana: $\quad c=-0.151, \quad$ China-Togo: $\quad c=2.040$, China-Senegal: $c=-0.714$, China-Benin: $c=1.382$ )

The estimation results of the model show that the regression model of China and the six African countries is good. The adjusted value of $R^{2}$ is about $94.9 \%$, which indicates that the independent variable has an explanation capacity of $94.9 \%$. In what concern, the significance level of the variables used, they have got a 5\% level at the significance test, which means that they passed it. From the regression equation of the case China-Ivory Coast, it can be said that when all the conditions remain unchanged, each $1 \%$ increase of the product number of GDP between the two countries, directly result in an increase of $0.633 \%$ of the number of the export value of China towards Ivory Coast. Similarly, each $1 \%$ increase of the product number of the population between the two countries results in an increase of $0.593 \%$ of the number of the export value of China towards Ivory Coast. This shows that the product number of GDP and the product number of the population between the two countries have a great impact on China export value to Ivory Coast. Thus, the increase of the GDP and of the population in both countries will increase the bilateral trade activities between the two countries.

\section{Trade Potential Analysis and Trade Value FORECASTING RESULTS}

Having found the empirical test results, it is now possible to predict the trade value between China and each of the six West African countries. Based on the results found after the application of the Eviews regression analysis with the weighted fixed effect model, $\mathrm{C}$ is replaced by -1.143 for Ivory Coast, -1.414 for Nigeria, -0.151 for Ghana, 2.040 for Togo, -0.714 for Senegal and 1.382 for Benin. $T$ ' represents the predicted trade value results found. In order to clearly indicate the relationship between the actual trade value and the predicted trade value between China and the six West African countries, $T$ ' which is the predicted trade value is divided by $T$ which is the actual trade value, $T^{\prime} / T$. The greater the value that will be found, the greater is the trade potential between the two countries, and the smaller the contrary. Normally if the ratio is around 1 , it indicates that the two countries have a good trade relationship. It can be seen from Table IV that China still has a large trade potential with Nigeria, Benin, Ivory Coast and Togo for the years coming, but with Senegal and Ghana the trade potential in the future is small. Before the year 2004, the trade potential between China and Ivory Coast was very small.
TABLE IV: ANALYSIS OF CHINA'S TRADE POTENTIAL WITH SIX WEST

\begin{tabular}{|l|l|l|l|l|l|l|}
\hline Years & $\begin{array}{l}\text { China } \\
\text { to Ivory } \\
\text { Coast }\end{array}$ & $\begin{array}{l}\text { China } \\
\text { to } \\
\text { Benin }\end{array}$ & $\begin{array}{l}\text { China } \\
\text { to } \\
\text { Ghana }\end{array}$ & $\begin{array}{l}\text { China } \\
\text { to } \\
\text { Nigeria }\end{array}$ & $\begin{array}{l}\text { China } \\
\text { to } \\
\text { Senegal }\end{array}$ & $\begin{array}{l}\text { China } \\
\text { to Togo }\end{array}$ \\
\hline 2001 & 0.49 & 0.78 & 1.59 & 0.94 & 1.50 & 1.36 \\
\hline 2002 & 0.65 & 1.14 & 1.52 & 1.05 & 1.57 & 1.33 \\
\hline 2003 & 0.78 & 1.29 & 1.08 & 0.73 & 1.59 & 0.93 \\
\hline 2004 & 1.71 & 1.30 & 0.84 & 0.99 & 1.33 & 0.86 \\
\hline 2005 & 1.75 & 0.93 & 0.81 & 0.95 & 1.29 & 0.80 \\
\hline 2006 & 1.24 & 0.73 & 1.12 & 1.01 & 1.10 & 0.73 \\
\hline 2007 & 0.87 & 0.69 & 0.99 & 0.97 & 0.82 & 0.54 \\
\hline 2008 & 0.90 & 0.78 & 0.90 & 0.73 & 0.90 & 1.03 \\
\hline 2009 & 1.03 & 1.01 & 1.06 & 0.89 & 0.97 & 1.18 \\
\hline 2010 & 1.10 & 0.98 & 1.09 & 1.25 & 0.90 & 1.12 \\
\hline 2011 & 1.31 & 0.96 & 0.89 & 1.12 & 0.82 & 1.22 \\
\hline 2012 & 1.01 & 1.30 & 0.66 & 1.31 & 0.78 & 0.74 \\
\hline 2013 & 1.02 & 1.23 & 0.95 & 1.18 & 0.71 & 1.21 \\
\hline 2014 & 0.91 & 1.19 & 0.87 & 1.06 & 0.47 & 1.45 \\
\hline
\end{tabular}

But there was a rapid increase trend in the years 2004 and 2005. After the year 2006, the ratio changed a little bit though the trade potential remains good. This means that the predicted export value is almost identical to the actual data. In Table $\mathrm{V}$ below, the same method is used again to confirm its accuracy for the year 2015. The results found on Table V, are a proof that this method is good. China export trade value to foreign countries differs from one country to another. The six West African countries mentioned are different, thus the export trade values and predicted values between each country with China are different. It can be seen from the table below that China predicted trade values of Ivory Coast and Nigeria are relatively accurate. The predicted values to Benin and Togo are higher than their actual real values while for the case of Senegal and Ghana, their predicted values are smaller than their real actual values. This can be explained by the fact that a predicted value can never be equal to an actual value and the results found are based on the factors chosen for this research. The data presented in the Table $\mathrm{V}$ give an idea on whether yes or no there is a large trade potential between the two countries.

This study focuses on China export trade value to Ivory Coast and the Table V confirms that for the case of Ghana, during the year 2015, its trade potential with China kept decreasing. In that concern Senegal's trade potential with China, it kept stable though still small. China however keeps having a large trade potential with Nigeria, Ivory Coast, Togo and Benin.

Before forecasting, the China export trade value to Ivory Coast from the year 2016 to the year 2018, it is firstly important to find a suitable model that can be used with the existing data. Thus, a time series model is conducted to analyze the data of China export trade value to Ivory Coast during the period under study, from the year 2001 to the year 2015. Finally, an order autoregressive model is found to be the most appropriate model to use for forecasting. It is known that in general, economic data have a first-order lag auto correlation, thus the equation below is used and applied with Eviews 8.0 and the same data, to find an estimated equation:

$$
\log \left(T_{\mathrm{t}}\right)=\alpha+\beta \log \left(T_{t}(-1)\right)+u_{t}
$$

The Table VI gives the necessary results through Eviews 8.0 that will confirm the final equation to be used. The 
software itself adjusted the sample, making it cover the period of the years 2002-2015.

TABLE V: ANALYSIS OF China's TRAde POTENTIAL WITH SiX WEST AFRICAN COUNTRIES FOR THE YEAR 2015 (TRADE VALUE IN MiLLIONS OF US DOLLARS)

\begin{tabular}{|l|l|l|l|l|l|l|}
\hline Year 2015 & China to Ivory Coast & China to Benin & China to Ghana & China to Nigeria & China to Senegal & China to Togo \\
\hline Actual value & 1554.44 & 2989.07 & 5308.88 & 13701.24 & 2190.53 & 2180.17 \\
\hline Predicted value & 1426.32 & 4009.56 & 4364.02 & 13197.57 & 1021.85 & 3647.76 \\
\hline Trade potential & 0.92 & 1.34 & 0.82 & 0.96 & 0.47 & 1.67 \\
\hline
\end{tabular}

TABLE VI: FiRST ORdER LAG AUTO REGRESSIVE MODEL Sample (adjusted): 2002-2015

Included observations: 14 after adjustments

\begin{tabular}{lllll}
\hline \hline Variable & Coefficient & Std.Error & t-Statistic & Prob. \\
\hline \hline LOG(T(-1)) & 1.012233 & 0.007602 & 133.1587 & 0.0000 \\
\hline \hline
\end{tabular}

Based on the results found in Table VI, the estimated equation which will be used for the forecast is:

$$
\log \left(T_{t}\right)=1.0122 \log \left(T_{t}(-1)\right)
$$

Based on the residual sequence of (7), the Fig. 3 is a graph that is made in order to check if the fitted value found through the application of this equation is really similar to the actual value under study.

From the Fig. 3 below, it is noticed that the actual value (red line) and the fitted value (green line) are really close, meaning that the fitted value result can be accepted, and can be used to forecast. The Equation (7) is thus used to forecast China Export Trade Value to Ivory Coast from the year 2016 to the year 2018 .

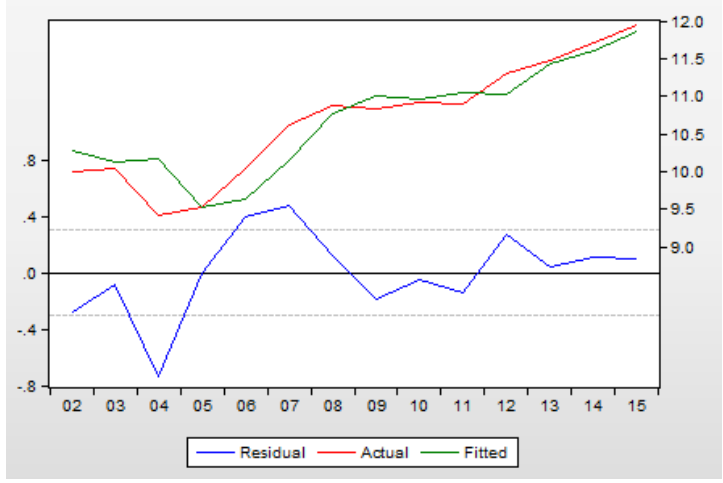

Fig. 3. Analysis graph of the fitted value of China export trade value to Ivory Coast (2002-2015).

It can be seen from the Table VII below that China export trade value to Ivory Coast will keep growing in the future.

TABLE VII: FORECASTING THE CHINA EXPORT TRADE VALUE TO IVORY

\begin{tabular}{|l|l|l|l|}
\hline COAST (2016-2018) IN MILLIONS OF US DOLLARS \\
\hline Years & 2016 & 2017 & 2018 \\
\hline $\begin{array}{l}\text { China Export Trade } \\
\text { Value to Ivory Coast }\end{array}$ & 1799.20 & 2086.25 & 2423.46 \\
\hline
\end{tabular}

This confirms that China "One Belt One Road" strategy and the Ivory Coast "emerging country by 2020" strategy are strategies that can be associated. China looks forward to expand its influence in the World while Ivory Coast strategy relies on a vision of capitalism, attracting foreign investors that will invest in different kind of sectors to boost the economic development of the country [28].

The Table VII forecast only covers the period 2016-2018 because the new container terminal financed by China will be operational in 2018. After the opening of this new terminal the trade volume and value between China and Ivory Coast will be surely boosted.

\section{SUGGESTED STRATEGIES}

With the faster growth of both Ivory Coast's population and GDP and its population having a higher demand for Chinese goods, which are cheap and easily affordable, China export trade value and volume to Ivory Coast will as shown in Table VII greatly increase in the coming years. Based on the research findings, it is clear that it is of greater beneficial and a necessity to develop the port of Abidjan. Thus, some strategies are suggested below, to promote the development of Abidjan port with the support from the China "One Belt One Road" strategy:

\section{A. Learn from the Chinese Experience}

Abidjan Port Authority should learn more about the development of Chinese ports, the different strategies used by Chinese not only to develop their ports but also to make them become the world most competitive ports.

Abidjan Port Authority should seize this opportunity regarding that China is providing total support in the development of Abidjan port, to establish more partnerships with other major ports in China.

\section{B. Ivory Coast Benefits from the China "One Belt One Road" Strategy}

As presented in Fig. 4 below, the China "One Belt One Road" strategy impact on Abidjan port will surely also boost the trade volume between Ivory Coast and other countries and other continents including Europe. Once the Abidjan port gets more developed, it will contribute to the globalization of this strategy, reinforcing the West Africa-Europe-China maritime route. This will surely generate more revenue to the country and directly contribute to the growth of the local economy and also create more job opportunities for locals.

The Fig. 5 below gives an authentic proof that goods coming from China and destined for Ivory Coast can firstly rich Europe by train as there is a direct train from China to Europe, then from Europe reach West Africa by maritime route as shown in Fig. 4.

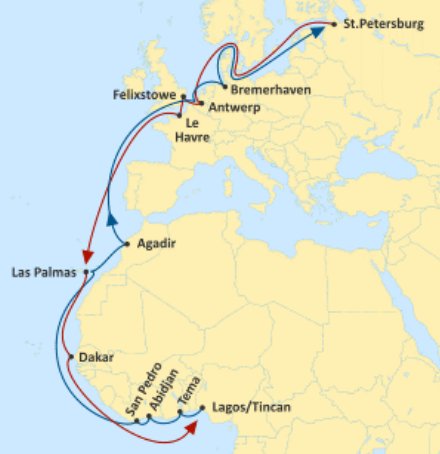

Fig. 4. West Africa to Europe maritime route. 


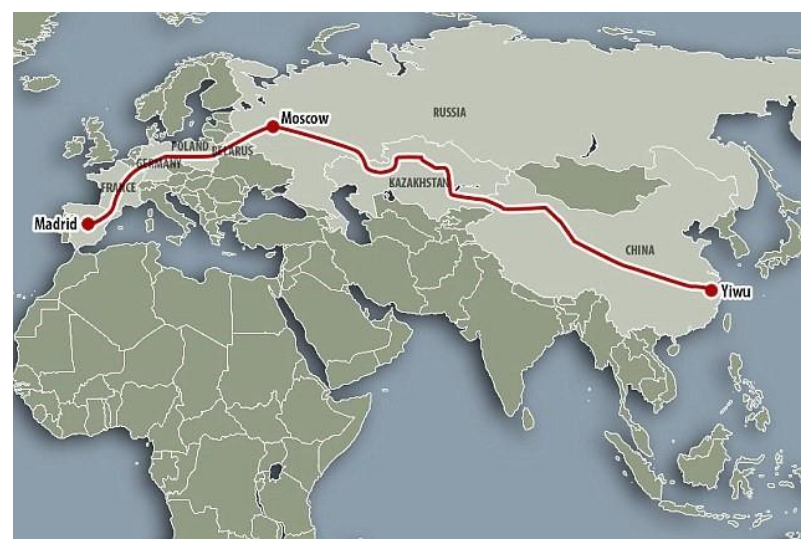

Fig. 5. China rail route to Europe.

This is another way to extend the China "One Belt One Road" strategy. This extended route will help to save time, to avoid pirates that are on the East African coast, and will also be less costly. Sending goods from China to Ivory Coast directly by ship, takes about 43 days while if the same goods are sent from China to Europe via railroad then from Europe to Ivory Coast via Maritime road, it will take about 30 days to arrive [29].

\section{Make Sure That the Abidjan Port Becomes a Hub Port}

Once the construction of the second container terminal of Abidjan which started in 2015, will be finished, it will help to double the port of Abidjan capacity. New policies that will promote this port can be implemented. The land area available for the cargo storage should be expanded while Abidjan port should improve its efficiency. Many of the most competitive and busiest ports in the world are to be found in China, thus the financial involvement of China made into the port of Abidjan can help this port to meet up international standards and become a hub port in West Africa.

\section{Set up a Good Hinterland Logistics Connectivity Network}

A logistic center can be built at the entrance of Abidjan city, from which customers coming from the hinterland can directly withdraw their goods or deposit goods that will be sent abroad via the Abidjan port without arriving at the port. This will help to decongest the port.

\section{E. Reduce Port Cost and Charges}

According to the Africa Infrastructure Country Diagnostic database, Abidjan port container cargo handling charge per TEU is $\$ 260$ per unit, this port has the highest charges rate in West Africa [30]. Reducing the cost and charges will surely attract more shipper lines.

\section{F. Promote Public-Private Investment}

For the development of Abidjan port, private investors will be needed, thus the Abidjan Port Authority should improve the infrastructure of the port and give some guarantees to investors. Indeed, having adequate infrastructure is an important factor to take into consideration by investors, when it comes to choosing a foreign country where to invest. By doing this, many Chinese and other foreign investors will be attracted and motivated to invest in Abidjan port. The outsourcing strategy can be used to transfer more activities of the port to the private sector.

\section{CONCLUSION}

The China - Ivory Coast cooperation is a great opportunity beneficial to both countries. This article demonstrates that the impact of the China "One Belt One Road" strategy on the development of Abidjan port is obvious. The results found through the application of the Gravity Model show that there is a large trade potential between the two countries. The insight of the findings of the population and the GDP being the two main factors affecting the trade between the two countries is that the population is a factor which in terms of import decides on the market scale and the level of consumption of a country while in terms of export decides on the number and the quality of the labor force. The GDP decides on the purchasing power of the citizens of a country. In Ivory Coast, the higher both factors will increase, the higher the country will keep importing from China, resulting in an increase in the trade volume. In the coming years, the China export trade value to Ivory Coast will have a good growth. The China "One Belt One Road" strategy will improve the influence of Abidjan port in West Africa and help the port to play a positive role in realizing the 2020 Ivory Coast emerging country strategy. The strategies proposed in this article, if applied, can contribute not only to the development of Abidjan port but also to the improvement of the fluidity of the supply chain for the hinterland countries, as the goods received through Abidjan Port are both beneficial to Ivory Coast and its neighboring countries.

\section{REFERENCES}

[1] L. Zhu, "The construction model of "One Belt and One Road" Mechanisms and platforms," Springer Singapore, pp. 111-127, 2016.

[2] C. P. Zhu, "The construction capability, challenges and the corresponding countermeasures of the 21st-Century Maritime Silk Road,” Springer Singapore, pp. 3-30, 2016

[3] W. Fasslabend, "The Silk Road: A political marketing concept for world dominance," European View, vol. 14, no. 2, pp. 293-302, 2015.

[4] H. Y. Wang and M. Lu, "One Belt, One Road and future directions for Chinese outbound investment," Palgrave Macmillan UK, pp. 172-186, 2016.

[5] J. Liu, "Development of regional logistics along the One Belt and One Road," Springer Singapore, pp. 77-101, 2016.

[6] F.-P. V. D. Putten and M. Meijnders, "China, Europe and the Maritime Silk Road," Netherlands Institute of International Relations, pp. 1-37, 2015.

[7] B. B. Niang, "Assessment of trade potential of Senegal and Morocco," Modern Economy, vol. 07, no. 1, pp. 27-38, 2016.

[8] G. Gebrehiwot and B. Gebru, "Ethiopia's foreign trade potential: Inferences from a dynamic gravity approach," International Journal of Economics and Business Research, vol. 9, no. 4, pp. 355-375, 2015.

[9] A. O. Luqman, N. A. A. Bakar, and A. A. M. Izraf, "The gravity model approach: An application on the ECO WAS trading bloc," South East European Journal of Economics and Business, vol. 11, no. 1, pp. 67-75, 2016.

[10] A. Sedjini and I. Kraja, "International trade of albania: Gravity model," European Journal of Social Sciences Education and Research, vol. 1, no. 3, pp. 219-227, 2014.

[11] Y. T. Mohmand, A. Salman, K. S. Mughal, M. Imran, and N. Makarevic, "Export potential of Pakistan: Evidence from the gravity model of trade," European Journal of Economic Studies, vol. 14, pp. 212-220, 2015.

[12] H. T. Karamuriro and W. N. Karukuza, "Determinants of Uganda'S export performance; A gravity model approach," International Journal of Economics and Business Research, vol. 4, no. 2, pp. 45-54, 2015.

[13] L. K. Jun, "Study of China's export trade flow based on gravity model," Master Degree thesis, School of Economy and Management, Harbin Institute of Technology, Harbin, China, 2009.

[14] T. Wang, "Under the "Belt and Road" Zhejiang clothing export trade potential analysis," Master Degree thesis, School of Economics and Management, Zhejiang Sci-Tech University, Hangzhou, 2016. 
[15] V. V. Trung and N. A. Thu, "Trade potential of climate smart goods of Vietnam: An application of gravity model," International Scientific Journal Geographica Pannonica, vol. 20, no. 1, pp. 8-18, 2016.

[16] E. Rasoulinezhad and G. S. Kang, "A panel data analysis of South Korea's Trade with OPEC member countries: The gravity model approach," Iran. Econ. Rev., vol. 20, no. 2, pp. 203-224, 2016.

[17] C.-C. Wang, Y.-H. Tu and H.-L. Wong, "The comparison between multivariate fuzzy time series and traditional time series modeling to forecasting China Exports," in Proc. Fourth International Conference on Innovative Computing, Information and Control, pp. 1487-1490, 2009.

[18] J. Ledolter, "Estimation bias in the first-order autoregressive model and its impact on predictions and prediction intervals," Communication in Statistics-Simulation and Computation, pp. 771-787, 2009

[19] A. A. Hatab, E. Romstad, and X. X. Huo, "Determinants of Egyptian agricultural exports: A gravity model approach," Modern Economy, vol. 1, pp. 134-143, 2010.

[20] G.-H. Estrella, "comparing alternative methods to estimate gravity models of bilateral trade," Empirical Economics, vol. 44, no. 3, pp. 1087-1111, 2013.

[21] Y. H. Tang and W. W. Wang, "An analysis of trade potential between China and ASEAN within China-ASEAN FTA," University of International Business and Economics (UIBE), China, pp. 1-17, 2006.

[22] COMTRAADE. [Online]. Available: www.comtrade.un.org

[23] The National Bureau of Statistics of China. [Online]. Available: www.stats.gov.cn

[24] Information on World Bank database. [Online]. Available: data.worldbank.org

[25] Distance Calculator. [Online]. Available: www.distancecalculator.net

[26] WTO. Available: Information on www.wto.org

[27] M. A. Elshehawy, H. F. Shen and R. A. Ahmed, "The factors affecting Egypt's Exports: Evidence from the gravity model analysis," Open Journal of Social Sciences, pp. 138-148, 2014.
[28] D. K. Duncan, Prime Minister of Côte d'ivoire, World Economic Forum Davos, 2016.

[29] CMA-CGM. [Online]. Available: www.cma-cgm.com

[30] A. M. Alanda, "Improving ports efficiency in West Africa," Doctoral Degree thesis, Department of Transportation and Management, Dalian Maritime University, Dalian, China, 2013.

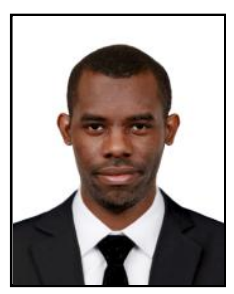

Pascal Kany Prud'ome Gamassa was born in Brazzaville, in the Republic of Congo. He obtained a Bachelor Degree in international economics and trade, and a Master Degree in international trade at Dalian Maritime University in Dalian, China. Since September 2015 he is a PhD student majoring in logistics engineering and management at the same University and is expected to graduate in July 2018. His research interests include international marketing, port management, logistic supply chain management and international finance.

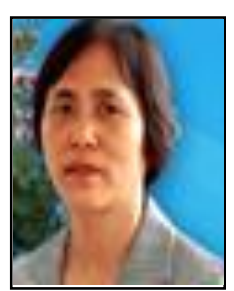

Yan Chen was born in Liaoning Province in China She obtained a Bachelor Degree in computer software at Dalian Maritime College, Dalian, China, in 1978, a Master Degree in computer application at Dalian Maritime College in 1989 and a PhD Degree in Management Science and Engineering at Dalian University of Technology in 2000. Prof. Chen is a professor in Transportation Management College of Dalian Maritime University, and the dean of the Key Laboratory in Liaoning Province on Logistics Shipping Management System Engineering. She has published three books and more than 100 papers. 